\title{
Morphometric Analysis for Planning Soil and Water Conservation Measures Using Geospatial Technique
}

\author{
Benukantha Dash", M.S.S. Nagaraju, Nisha Sahu, R.A. Nasre, D.S. Mohekar, \\ Rajeev Srivastava* and S.K. Singh
}
ICAR-National Bureau of Soil Survey and Land Use Planning (NBSS \& LUP), Amaravati Road, Nagpur-440 033, Maharashtra, India

*Corresponding author

\begin{abstract}
A B S T R A C T
Keywords

GIS,

Remote

sensing,

Morphometric

analysis, Soil and

water conservation,

Watershed

\section{Article Info}

Accepted:

17 December 2018

Available Online:

10 January 2019

Morphometric analysis with the help of Geographic Information System (GIS) is most effective, time saving and accurate technique for prioritization, planning and management, site specific suitability of various soil and water conservation measures and development and management of ground water on watershed basis. This study describes the morphometric analysis of Baruband watershed, Seoni district, Madhya Pradesh using remote sensing and GIS techniques for computation of morphometric parameter i.e linear, aerial and relief aspect and its use for planning of soil and water conservation measures. The analysis reveals that drainage pattern is dendritic and the maximum stream order of the watershed is four. The total number of stream of all orders is 119 with total length $5.995 \mathrm{~km}$. Out of all order $50.45 \%$ covered by $1^{\text {st }}$ order, $24.77 \%$ by $2^{\text {nd }}$ order, $22.93 \%$ by $3^{\text {rd }}$ order and $1.83 \%$ by $4^{\text {th }}$ order. The drainage density of the watershed is $0.297 \mathrm{~km} /$ sqkm. The mean bifurcation ratio of the watershed is 5.20. The values obtained through morphometric analysis indicates that the watershed has low drainage density, permeable sub soil and flatter peak runoff for longer duration which can be manage easily as compare to circular shape basin. The present study demonstrates the usefulness of remote sensing and GIS techniques for computation of morphometric parameter.
\end{abstract}

\section{Introduction}

Utilization of available natural resources is a major concern for all the stake holders. Soil and water are the two major natural resources which directly or indirectly affect the livelihood of the people. Planning and management of these two natural resources is need of the hour which is mostly affected by the growing population, industrialization, deforestation, etc. Watershed is an ideal unit for sustainable management of natural resources i.e land and water to mitigate the adverse effect of exploitation. Quality and quantity of immense data base are required for management of any watershed or drainage basin. As it is very difficult to get all the information, morphometric analysis are commonly done for solving the various hydrological problems of the watershed, planning and implementation of soil and water conservation measures, water resource 
development, ground water development and management, erosion control measures and many more.

Morphometry is the measurement and the mathematical analysis of the earth surface, shape and dimension of its landform (Strahler, 1964; Clarke, 1966; Agrawal, 1998) and can be done through measurement of linear, aerial and relief aspects of the basin and slope contribution (Ali, 1988; Nag and Chakraborty, 2003; Magesh et al., 2012; Sahu et al., 2016). Morphometric analysis is an important aspect for characterization of watersheds and provides a quantitative description of the drainage system (Strahler, 1964) and useful for hydrological investigation. The influence of drainage morphometry is very significant in understanding the landform process, soil physical properties and erosional characteristics (Rai et al., 2014). Drainage lines of an area not only explain the existing three dimensional geometry of the region but it also help to describe its evolutional process (Singh, 1980). Several variables influenced the development of drainage system and the flowing pattern over space and time (Horton, 1945; Leopold and Maddock, 1953; Abrahams 1984). Various hydrological parameters can be correlated with shape, size, slope, drainage density etc. of the basin (Rastogi and Sharma, 1976; Magesh et al., 2012). The surface runoff and flow intensity of the drainage system can be estimated using the geomorphic features associated with morphometric parameters (Ozdemir and Bird, 2009). Various researchers used conventional methods to study the drainage characteristics of many river basins and sub-basins in different parts of the globe (Horton 1945; Strahler 1957, 1964; Krishnamurthy et al., 1996). Integration of Remote Sensing (RS) and Geographical Information Systems (GIS) techniques are more convenient for morphometric analysis as compare to conventional method. It is a proven technique for delineating, updating and analyzing the morphometric parameters of drainage basin and effective planning and management of natural resources is more suitable than other methods. A number of morphometric analysis have been carried out by using the RS and GIS in different watersheds as well as in various river basin and sub basin. Hence, the present study is carried to evaluate the various morphometric parameters of the Baruband watershed by using GIS tools for planning and management of natural resources.

\section{Materials and Methods}

\section{Study area}

The study area lies between $22^{0} 28^{\prime} 32.77^{\prime \prime}$ to $22^{\circ} 32$ ' 57.43" N latitudes and $79^{\circ} 41$ ' 35.91" to $79^{\circ} 44^{\prime} 10.02$ " E longitudes in Seoni district, Madhya Pradesh with an area of $20.17 \mathrm{~km}^{2}$. The elevation varies from $439 \mathrm{~m}$ to $607 \mathrm{~m}$ from mean sea level (MSL). The watershed comes under the catchment area of Wainganga River, a tributary of Godavari River. It is situated in the Agro-ecological sub-region (AESR) 10.4 which is Central Highlands (Malwa and Bundelkhand), Hot Sub-humid (Dry) Eco-sub-region. The soil temperature regime is hyperthermic and soil moisture regime is ustic. The major crop in kharif season are soybean, paddy, maize, pigeon pea, gram and in rabi season are wheat and chick pea. The location map of the study area is shown in Figure 1.

The morphometric analysis of the watershed has been carried out with the help of Survey of India (SoI) toposheet on 1:50000 and Cartosat-I DEM (30m resolution) data using ArcGIS software. The drainage thematic layer extracted from Cartosat-I DEM was together superimposed on SOI toposheet for further rectification. Parameter like area, perimeter, drainage network, maximum length of 
watershed, stream order wise length and number of stream and watershed relief values of the watershed were calculated using ArcGIS software for morphometric analysis. Morphometric parameters are calculated based on the formulae shown in Table 1 and grouped into three categories i.e. linear, aerial and relief aspects.

\section{Results and Discussion}

\section{Linear morphometric parameters}

The linear morphometric parameters were computed using the standard formulae as given in Table 1. First step of morphometric analysis is the designation of stream order and Strahler (1964) method is used for designation of stream order and defined the position of streams in the hierarchy of tributaries. A total of 109 streams found in the watershed spreading over an area of 20.17 square kilometer. The length and number of streams in each order is presented in Table 2. Maximum stream order of the watershed is of fourth order. It is revealed that, out of all stream order $50.45 \%$ is $1^{\text {st }}$ order, $24.77 \%$ is $2^{\text {nd }}$ order, $22.93 \%$ is $3^{\text {rd }}$ order and $1.83 \%$ is $4^{\text {th }}$ order.

It is observed from Table 2 that number of streams decreases with increase in stream order $\left(r^{2}=0.794\right)$, which is satisfactory (Fig. 2) and it supports Horton (1932) "law of stream numbers". Stream length also conform Horton (1945) "law of stream length" (Fig. 3). The length of stream decreases as stream order increases which indicates basin evolution follows the erosion laws acting on geological material with homogenous weathering erosion characteristics $\left(r^{2}=0.90\right)$.

In general, mean stream length increases with increase in stream order but it fails in case of second order stream may be due to slope and topography variations. The value varied from
$51.7 \mathrm{~m}$ to $105.50 \mathrm{~m}$ and the stream length ratio ranged from 0.98 to 1.75 for the watershed. Increasing trend observed for stream length ratio from lower order to higher order and indicates the mature geomorphic stages of study area. If there is change from one order to another order, it indicates their late youth stage of geomorphic development (Singh and Singh, 1977). Horton (1945) considered bifurcation ratio $\left(\mathrm{R}_{\mathrm{B}}\right)$ as an index of reliefs and dissections. In the present study, $\mathrm{R}_{\mathrm{B}}$ varies from 1.08 to 12.5 from one order to next order which indicates that irregularities are attributed to geological and lithological development of a drainage basin (Strahler, 1964). The mean value of $R_{B}$ is 5.20, high value is the indication of complexity in nature (Nag and Chatroborty, 2003). The watershed having lower value of $\mathrm{Rb}$ indicates the area suffered less structural disturbances (Strahler, 1964; Nag, 1998). In the present study, a higher $\mathrm{Rb}$ value shows strong structural disturbances occurred in the watershed when the underlying geological structure transforming from one series to another series (Withanage, 2014; Naitam et al., 2016). The higher $\mathrm{R}_{\mathrm{B}}$ values of all orders (1.08 to 12.5 ) and the higher average $R_{B}$ value (5.2) with the elongated shape of the watershed may result a lower and extended peak flow.

\section{Aerial morphometric parameters}

Aerial aspects of the watershed are computed and given in Table 3. The total area of the watershed is $20.17 \mathrm{~km}^{2}$, perimeter is 25.378 $\mathrm{km}$ and length of the watershed is $7242 \mathrm{~m}$. Drainage texture is one of the important parameter of the drainage basin and shows relative spacing of drainage lines, which are more prominent in impermeable material as compared to permeable ones (Ali and Khan, 2013). Infiltration capacity of soil is the dominant factor influencing drainage texture which includes drainage density and stream frequency as well (Horton, 1945). It mainly 
depends upon a number of natural factors such as climate, rainfall, vegetation, rock and soil type, relief and stage of development. Drainage texture can be grouped into five categories i.e., very coarse $(<2)$, coarse $(2-4)$, moderate (4-6), fine (6-8) and very fine (>8) (Smith 1954). The study area has drainage texture value of 4.29 which falls under moderate texture category.

Drainage density provide information about the permeability and porosity of the watershed and selection of artificial recharge site (Krishnamurty et al., 2001) for ground water development and interpreted the relationship between climate and geology (Ritter and Major, 1995). The rainfall characteristics influence the quantity of surface runoff. Low drainage density generally found in areas of permeable subsoil material or highly resistant rocks, dense vegetation and low relief whereas high drainage density results due to weak or impermeable subsurface material, sparse vegetation and mountainous relief (Nag, 1998). Density of vegetation and infiltration capacity of soils, influence the rate of surface run-off and affects the drainage density of an area. Low drainage density indicates coarse drainage texture whereas high drainage density leads to fine drainage texture (Ali and Khan, 2013). The watershed has drainage density $0.297 \mathrm{~km} / \mathrm{km}^{2}$, indicates that the watershed has high permeable sub soil. Stream frequency indicates the stream network distribution over the watershed and it has a value of 0.054 per ha which indicates that the study area has a low relief and almost flat topography (Horton, 1932). Another important parameter of the morphometric analysis is texture ratio which depends on the underlying lithology, infiltration capacity, and relief aspect of the terrain (Demoulin, 2011; Altin and Altin, 2011). The watershed has a texture ratio of 2.16 and categorized as moderate in nature.
The circulatory ratio is influenced by many factors like land use/ land cover, geological structures, length and frequency of stream and it describe as a significant ratio that indicates the dendritic pattern of a watershed (Miller, 1953). Circularity ratio ranges from 0.4 to 0.5 that indicates strongly elongated and permeable homogenous geologic materials (Withanage, 2014). Higher value of circulatory ratio, greater the circular shape of the basin and vice-versa. The circulatory ratio of the watershed is 0.39 results the lack of circulatory and shows that the watershed is elongated in shape, low runoff and highly permeable sub soil conditions (Miller, 1953). This reveals that, the study area is favourable for artificial ground water recharge.

Elongation ratio represents the shape of the watershed and gives an idea about hydrological characteristics of a watershed. This value generally varies from 0.6 to 1.0 over wide climatic and geologic types (Strahler 1964; Mustafa and Yusuf, 1999). Values near to one correspond to low relief, whereas values ranges between 0.6 and 0.8 represent the steep ground slope and high relief (Strahler, 1964). The varying slopes of basin can be categorized using index of elongation ratio i.e. circular $(0.9-1.0)$, oval (0.8-0.9), less elongated (0.7-0.8), elongated $(0.5-0.7)$ and more elongated $(<0.5)$ (Withanage et al., 2014). The elongation ratio of the study area is 0.69 and the watershed is classified as elongated. This indicates that the length of flow of runoff water over the basin will be for longer period, time of concentration will be more, develop flatter peak of flow, lower erosion and transport capacities (Singh and Singh 1977; Mustafa and Yusuf, 1999).

The form factor indicates the flow intensity of a basin (Horton, 1945) and has direct relationship between stream flow and shape of the watershed (Sahu et al., 2016). Form 
factor value would be always less than 0.7854 for all basins other than circular basin. Smaller value of form factor indicates the elongated basin. The form factor of the watershed is 0.38 which indicates it is elongated in nature with lower peak flows for longer duration which can be easily managed as compare to circular basin (Singh and Singh, 1997).

Length of overland flow is independent variables affecting physiographic and hydrological development of watershed (Horton, 1945). It is inversely related to the average slope of the channel and significantly affected by infiltration and percolation through the soil. It is synonymous with length of sheet flow as quite commonly used to a large degree and value for this watershed is 1.68. The value of constant of channel maintenance of the watershed is 3.36 which measures the area required to maintain each unit length of a stream (Schumm, 1956; Singh, 1995).

\section{Relief morphometric parameters}

Relief morphometric parameters used for the assessment of morphological characteristics of topography (Gayen et al., 2013). Relief aspects are related with three dimensional features i.e. area, volume and altitude of landform to analyze different geohydrological characteristics (Sahu, et al., 2016, Withanage et al., 2014). Relief parameters of the watershed are estimated (Table 3). The relief of the watershed is 0.168 $\mathrm{km}$. The relief ratio gives idea about overall steepness of a drainage basin and the intensity of erosional process operating on the slope of the basin (Schumn, 1956). The value of the watershed is 0.023 which is low and indicates basement rock and moderate relief. The watershed has ruggedness number of 0.05 which indicates less prone to the soil erosion.

\section{Hydrological inference and soil and water conservation planning}

The quantitative analysis of morphometric parameters is very much useful for prioritization of watershed, planning for site specific soil and water conservation measures and watershed management. Analysis of morphometric values of the study area revealed that the watershed has low runoff potential, lower and extended peak flow, permeable sub soil and high infiltration capacity. Storing of runoff water in surface through water harvesting structure for future use may not be the viable option due to permeable sub soil and high infiltration capacity. Construction of artificial recharge structure like percolation tank for ground water development and management and withdrawal of ground water for life saving irrigation in kharif and rabi season can be better option. Low runoff potential indicates that the watershed is less prone to soil erosion. Hence biological measures like vegetative barriers, hedge row, etc. and low cost engineering measures like contour bunding, field bunding with vegetative barrier, brushwood check dam, loose boulder check dam etc. may be useful for controlling soil erosion. Permanent check dam in the $3^{\text {rd }}$ and $4^{\text {th }}$ order stream can help the ground water recharge and stabilization of gully. Staggered contour trenching in the upstream of the watershed will be useful for in-situ moisture conservation.

The study can be used for site suitability analysis of various soil and water conservation structures and can be helpful for planning and management of the watershed. Other parameters like land use/land cover, land form, geology, soil can be used for making decision for site specific soil and water conservation measures and artificial ground water recharge structures. 
Table.1 Methodology used for computation of morphometric parameters

\begin{tabular}{|c|c|c|c|}
\hline $\begin{array}{l}\text { Sl. } \\
\text { no }\end{array}$ & $\begin{array}{l}\text { Morphometric } \\
\text { parameters }\end{array}$ & Formula/relationship & Reference \\
\hline \multicolumn{4}{|c|}{ Linear aspects } \\
\hline 1 & Stream order & Hierarchical rank & Strahler (1964) \\
\hline 2 & Stream length & Length of stream & Horton (1945) \\
\hline 3 & \begin{tabular}{c|c} 
Mean stream & l \\
length $\left(\mathrm{L}_{\mathrm{sm}}\right)$
\end{tabular} & $\begin{array}{l}\mathrm{L}_{\mathrm{sm}}=\mathrm{L}_{\mathrm{u}} / \mathrm{N}_{\mathrm{u}} \text {, where } \mathrm{Lu} \text { is total stream length of order" } \mathrm{u} \text { " } \\
\mathrm{Nu} \text { is total number of stream of order } \mathrm{u}\end{array}$ & Strahler (1964) \\
\hline 4 & $\begin{array}{l}\text { Stream length } \\
\text { ratio }\left(\mathrm{R}_{\mathrm{L}}\right)\end{array}$ & $\begin{array}{l}R_{L}=L_{u} / L_{u-1} \text {, where } L u \text { is total stream length of order " } u \text { " } \\
L_{u-1} \text { is total stream length of its next lower order }\end{array}$ & Horton (1945) \\
\hline 5 & $\begin{array}{l}\text { Bifurcation ratio } \\
\left(\mathrm{R}_{\mathrm{B}}\right)\end{array}$ & $\begin{array}{l}R_{B}=N_{u} /\left(N_{u+1}\right) \text { where, } N_{u} \text { is total number of stream order } u \\
\text { and } N_{u+1} \text { is total number of stream of the next higher order }\end{array}$ & Schumn (1956) \\
\hline 6 & $\begin{array}{l}\text { Mean bifurcation } \\
\text { ratio }\left(\mathrm{R}_{\mathrm{Bm}}\right)\end{array}$ & $\begin{array}{l}\mathrm{R}_{\mathrm{Bm}} \text { is average value of the bifurcation ratio of all stream } \\
\text { order }\end{array}$ & Strahler (1957) \\
\hline \multicolumn{4}{|c|}{ Aerial aspects } \\
\hline 7 & $\begin{array}{l}\text { Drainage texture } \\
\left(D_{t}\right)\end{array}$ & $\begin{array}{l}D_{t}=N_{u} / p \text {, where } N u \text { is the total number of stream of all } \\
\text { order and } \mathrm{P} \text { is the perimeter of the basin } \mathrm{km}\end{array}$ & Horton (1945) \\
\hline 8 & Texture ratio $\left(\mathrm{R}_{\mathrm{t}}\right)$ & $\begin{array}{l}\mathrm{R}_{\mathrm{t}}=\mathrm{N} 1 / \mathrm{P} \text { where } \mathrm{N} 1 \text { is total number of stream of first } \\
\text { order and } \mathrm{P} \text { is the perimeter of the watershed }\end{array}$ & Horton (1932) \\
\hline 9 & $\begin{array}{l}\text { Drainage density } \\
\text { (D) }\end{array}$ & $\begin{array}{l}\mathrm{D}=\mathrm{L}_{\mathrm{u}} / \mathrm{A} \text { where } \mathrm{Lu} \text { is total stream length of all order, } \\
\mathrm{km} \text { and } \mathrm{A} \text { is the area of the watershed, } \mathrm{km}^{2}\end{array}$ & Horton (1932) \\
\hline 10 & $\begin{array}{l}\text { Stream frequency } \\
\left(\mathrm{F}_{\mathrm{s}}\right)\end{array}$ & $\begin{array}{l}F_{s}=N_{u} / A \text {, where Nu is the total number of stream of all } \\
\text { order and } A \text { is the area of the watershed }\end{array}$ & Horton (1932) \\
\hline 11 & Form factor $\left(F_{f}\right)$ & $\begin{array}{l}\mathrm{F}_{\mathrm{f}}=\mathrm{A} / \mathrm{Lb}^{2} \text { where } \mathrm{A} \text { is the area of the watershed and } \mathrm{L}_{\mathrm{b}} \\
\text { Length of the basin, } \mathrm{km}\end{array}$ & Horton (1932) \\
\hline 12 & $\begin{array}{l}\text { Circulatory ratio } \\
\left(\mathrm{R}_{\mathrm{c}}\right)\end{array}$ & $\begin{array}{l}\mathrm{R}_{\mathrm{c}}=4 \pi \mathrm{A} / \mathrm{P}^{2} \text { where } \mathrm{A} \text { is the area of the watershed and } \\
\mathrm{P} \text { is the perimeter of the watershed }\end{array}$ & Miller (1953) \\
\hline 13 & $\begin{array}{l}\text { Elongation ratio } \\
\left(\mathrm{R}_{\mathrm{e}}\right)\end{array}$ & $\begin{array}{l}\mathrm{R}_{\mathrm{e}}=2 \mathrm{sqrt}(\mathrm{A} / \pi) \mathrm{Lb} \text {, where } \mathrm{A} \text { is the area, } \mathrm{km}^{2} \text { and } \\
\mathrm{L}_{\mathrm{b}} \text { length of the basin }\end{array}$ & Schumn (1956) \\
\hline 14 & $\begin{array}{l}\text { Length of overland } \\
\text { flow }\left(\mathrm{L}_{\mathrm{g}}\right)\end{array}$ & $\mathrm{L}_{\mathrm{g}}=1 /(\mathrm{D} * 2)$, where $\mathrm{D}$ is drainage density & Horton (1945) \\
\hline 15 & $\begin{array}{l}\text { Constant of } \\
\text { channel } \\
\text { maintenance }\end{array}$ & $1 / \mathrm{D}$, where $\mathrm{D}$ is the drainage density & Schumn (1956) \\
\hline \multicolumn{4}{|c|}{ Relief aspects } \\
\hline 16 & Relief & $\begin{array}{l}\text { Elevation at outlet of watershed - Elevation at highest } \\
\text { point on the watershed }\end{array}$ & Schumn (1956) \\
\hline 17 & Relief ratio $\left(R_{r}\right)$ & $\begin{array}{l}\mathrm{R}_{\mathrm{r}}=\mathrm{H} / \mathrm{Lb} \text {, where } \mathrm{H} \text { is the total relief of the watershed } \\
\text { andLb is the basin length }\end{array}$ & Schumn (1956) \\
\hline 18 & $\begin{array}{l}\text { Ruggedness } \\
\text { number }\left(\mathrm{R}_{\mathrm{n}}\right)\end{array}$ & $\begin{array}{l}\mathrm{R}_{\mathrm{n}}=\mathrm{H} * \mathrm{D} \text {, where } \mathrm{H}=\text { watershed relief, } \mathrm{km} \text { and } \mathrm{D} \text { is } \\
\text { the drainage density }\end{array}$ & Strahler (1964) \\
\hline
\end{tabular}


Table.2 Drainage network of the study area

\begin{tabular}{|l|c|c|c|c|c|}
\hline $\begin{array}{l}\text { Stream } \\
\text { order }\end{array}$ & $\begin{array}{c}\text { No of Stream } \\
\text { (nos) }\end{array}$ & $\begin{array}{c}\text { Total length of } \\
\text { streams }(\mathbf{m})\end{array}$ & $\begin{array}{c}\text { Mean streams } \\
\text { length }(\mathbf{m})\end{array}$ & $\begin{array}{c}\text { Bifurcation } \\
\text { ratio }\end{array}$ & $\begin{array}{c}\text { Stream } \\
\text { length ratio }\end{array}$ \\
\hline $\mathbf{1}$ & 55 & 2887 & 52.49 & & \\
\hline $\mathbf{2}$ & 27 & 1396 & 51.70 & 2.03 & 0.98 \\
\hline $\mathbf{3}$ & 25 & 1501 & 60.04 & 1.08 & 1.16 \\
\hline $\mathbf{4}$ & 2 & 211 & 105.50 & 12.5 & 1.75 \\
\hline Total & 109 & 5995 & 67.43 & Avg 5.2 & \\
\hline
\end{tabular}

Table.3 Aerial and relief aspects of the study area

\begin{tabular}{|l|l|l|l|}
\hline $\begin{array}{l}\text { Morphometric } \\
\text { parameters }\end{array}$ & $\begin{array}{l}\text { Estimated } \\
\text { values }\end{array}$ & Morphometric parameters & Estimated values \\
\hline Area & $20.17 \mathrm{~km}^{2}$ & Circulatory ratio & 0.39 \\
\hline Perimeter & $25.378 \mathrm{~km}$ & Elongation ratio & 0.69 \\
\hline Length of basin & $7242 \mathrm{~m}$ & Length of overland flow & 1.68 \\
\hline Drainage texture & 4.29 & Constant of channel maintenance & $3.36 \mathrm{~km}^{2} / \mathrm{km}$ \\
\hline Texture ratio & 2.16 & Relief & $0.168 \mathrm{~km}$ \\
\hline Drainage density & $0.297 \mathrm{~km} / \mathrm{km}^{2}$ & Relief ratio & 0.023 \\
\hline $\begin{array}{l}\text { Stream frequency } \\
\text { frem factor }\end{array}$ & $0.054 \mathrm{per} \mathrm{ha}$ & Ruggedness number & 0.05 \\
\hline Form fan & 0.38 & & \\
\hline
\end{tabular}

Fig.1 Location map of watershed

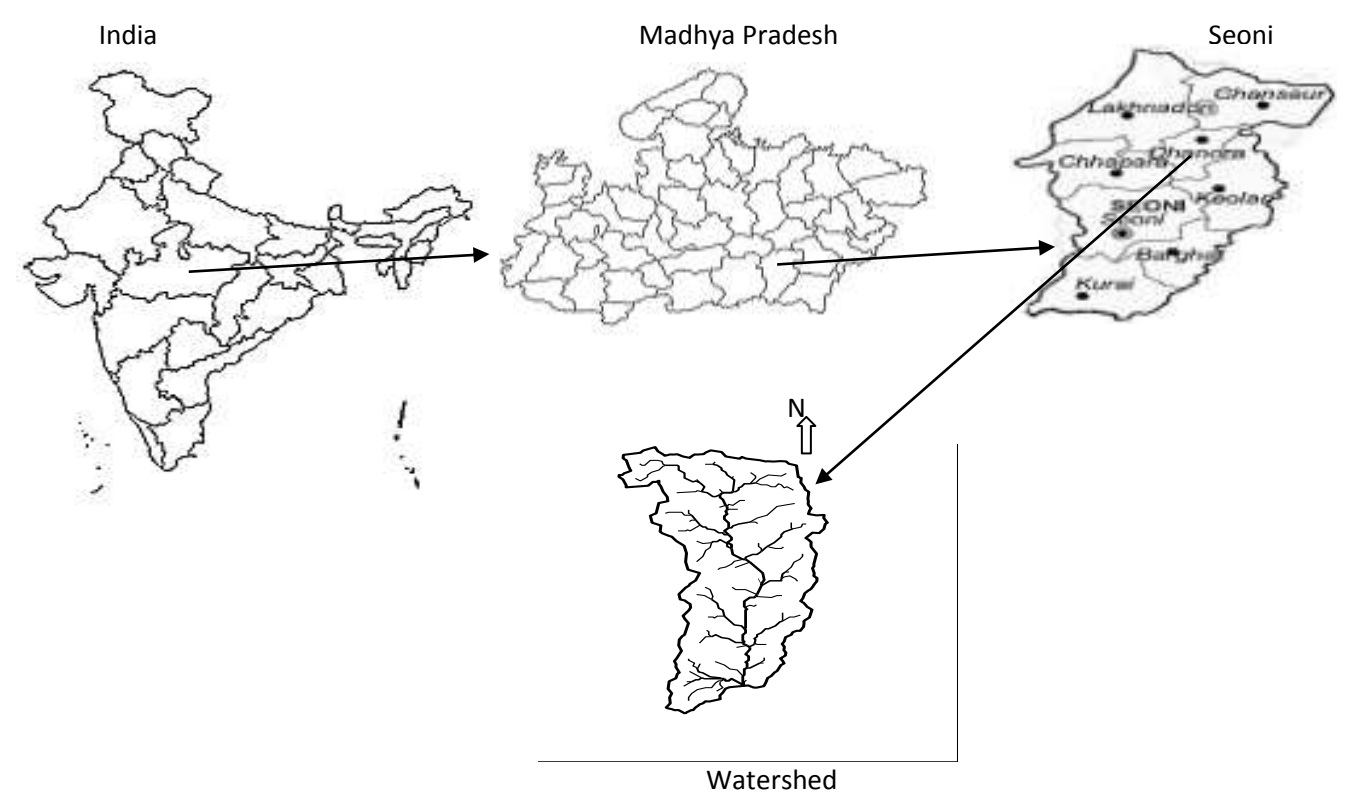


Fig.2 Regression of logarithm of number of streams and stream order

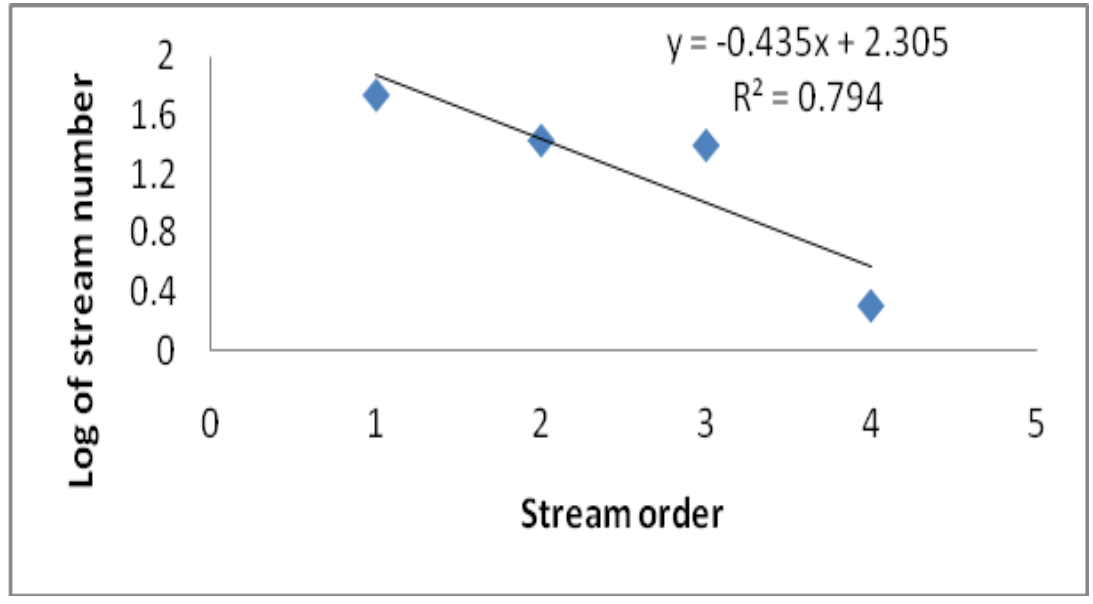

Fig.3 Regression of logarithm of cumulative stream length and stream order

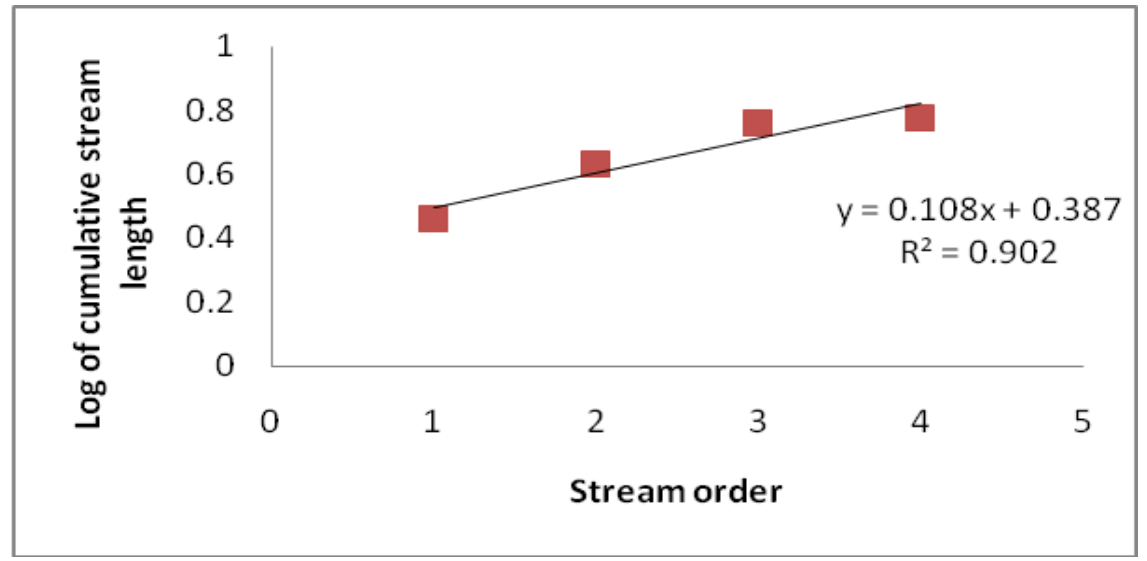

Morphometric analysis results that low runoff may generate from this watershed and less prone to erosion, biological measures in arable land and temporary soil and water conservation measures in gully may be adopted to control soil erosion. Morphometric analysis indicates that the soil is permeable, so artificial ground water recharge may be more useful than surface water harvesting.

\section{References}

Abrahams, A.D. 1984. Channel networks: a geomorphological perspective. Water
Resource Res. 20:161-168.

Agarwal, C.S. 1998. Study of drainage pattern through aerial data in Naugarh area of Varanasi district U.P. J Indian Soc. Remote Sensing. 24(4):169-175.

Ali, Syed Ahmad and Khan, Nazia. 2013. Evaluation of Morphometric Parameters -A Remote Sensing and GIS Based Approach. Open Journal of Modern Hydrology, http://dx.doi.org/ 10.4236/ojmh.2013.31004.

Altin, T.B. and Altin, B.N. 2011. Drainage morphometry and its influence on landforms in volcanic terrain, Central 
Anatolia, Turkey. Procedia -Social and Behavioural Sciences.19: 732740.

Clarke, J.I. 1966. Morphometry from maps. Essays in geomorphology. Elsevier Publ. Co., New York, 235-274.

Demoulin, A. 2011. Basin and river profile morphometry: a new index with a high potential for relative dating of tectonic uplift. Geomorphology. 126 (1-2): 97107.

Leopold, L. B and Maddock, T. 1953. The hydraulic geometry of stream channels and some physiographic implications. USGS professional paper. 252: 1-57.

Gayen S, Bhunia, G. S. and Shi, P. K. 2013. Morphometric analysis of Kangshabati-Darkeswar Interfluves area in West Bengal, India using ASTER DEM and GIS techniques. Geol Geosci. 2(4): 1-10.

Horton, R.E. 1932. Drainage basin characteristics. Trans Am. Geophys Union.13:350-361.

Horton, R.E. 1945. Erosional development of streams and their drainage basins; hydrophysical approach to quantitative morphology. Geol Soc Am Bull. 56: 275-370.

Krishnamurthy, J., Venkatesa Kumar, N., Jayaraman, V. and Manivel. 2001. An Approach to Demarcate Ground Water Potential Zones through Remote sensing and Geographical information system. International Journal of Remote sensing, 17(10): 1867-1884.

Magesh N.S, Chandrasekar, N. and Kaliraj, S. 2012. A GIS based automated extraction tool for the analysis of basin morphometry. Bonfring Int J Ind Eng Manag Sci. 2(1): 32-35.

Miller, V.C. 1953. 1953. A quantitative geomorphic study of drainage basin characteristics in the Clinch Mountain area, Virginia and Tennessee. Proj. NR 389-402. Tech Rep 3, Columbia
University, Department of Geology, ONR, New York.

Mustafa, S. and Yusuf, M. I. 1995. A textbook of hydrology and water resources, I edn. Jenas Prints and Publishing Company, Abuja (Chapter 5).

Nag, S.K. 1998. Morphometric Analysis Using Remote Sensing Techniques in the Chaka Sub Basin, Purulia District, West Bengal. Journal of the Indian Society of Remote Sensing. 26 (1-2): 69-76.

Nag, S.K, and Chakroborty, S. 2003. Influence of rock types and structures in the development of drainage networks in hard rock area. $J$ Indian Soc. Remote Sensing. 31(1): 25-35.

Naitam, R.K., Singh, R.S., Sharma, R.P., Verma, T.P. and Arora, Sanjay. 2016. Morphometric analysis of ChanavadaII watershed in Aravali hills of southern Rajasthan using geospatial technique. Journal of Soil and Water Conservation. 15(14):318-324.

Ozdemir, H and Bird, D. 2009. Evaluation of morphometric parameters of drainage networks derived from topographic maps and DEM in point floods. Environ Geol. 56: 1405-1415.

Raj, Praveen Kumar, Mohan, Kshitij, Mishra, Sameer, Ahmad, Aariz and Mishra, Varun Narayan. 2014. A GIS-based approach in drainage morphometric analysis of Kanhar River Basin, India. Applied Water Science. DOI 10.1007/s13201-014-0238-y.

Rastogi, R.A and Sharma, T.C. 1976. Quantitative analysis of drainage basin characteristics. J. Soil Water Conservation India. 26(14):18-25.

Ritter, F. E. and Major, N.P. 1995. Useful Mechanisms for Developing Simulations for Cognitive Models. AISB Quarterly. 91: 7-18.

Sahu, Nisha, Reddy, G. P. Obi, Kumar, 
Nirmal, Nagaraju, M. S. S., Srivastava, Rajeev and Singh, S. K.2016. Morphometric analysis in basaltic Terrain of Central India using GIS techniques: a case study. Applied Water Science. DOI 10.1007/s13201016-0442-z.

Schumn, S.A. 1956. Evaluation of drainage systems and slopes in badlands at Perth Amboy, New Jersy. Bull Geol. Soc. Am. 67:597-646.

Singh, S. 1995. Quantitative analysis of watershed geomorphology using remote sensing techniques. Ann Arid Zone. 34(4): 243-25.

Singh, K.N. 1980. Quantitative analysis of land forms and settlement distribution in southern uplands of eastern Uttar Pradesh (India). Vimal Prakashan, Varanasi.

Singh, S. and Singh, M.C. 1977.
Morphometric analysis of Kanhar River Basin.Natl. Geogr. J India. 43(1):1-43 (1977).

Smith, K. G. 1954. Standards for grading texture of erosional topography. Am. $J$ Sci. 248: 655-668.

Strahler, A.N. 1957. Quantitative analysis of watershed geomorphology. Trans. Am. Geophys. Union. 38:913-920.

Strahler, A.N. 1964. Quantitative geomorphology of drainage basin and channel networks. Hand book of applied hydrology. McGraw Hill, New York (section 4-11).

Withanage, N.S., Dayawansa, N.D.K., and Silva, R.P. 2014. Morphometric analysis of the Gal Oya river basin using spatial data derived from GIS. Tropical Agric. Res. 26(1): 175-188.

\section{How to cite this article:}

Benukantha Dash, M.S.S. Nagaraju, Nisha Sahu, R.A. Nasre, D.S. Mohekar, Rajeev Srivastava and Singh, S.K. 2019. Morphometric Analysis for Planning Soil and Water Conservation Measures Using Geospatial Technique. Int.J.Curr.Microbiol.App.Sci. 8(01): 2719-2728. doi: https://doi.org/10.20546/ijcmas.2019.801.287 